\title{
Best Practice BRT for Increase TransJakarta Modal Share
}

\author{
Adhi Muhtadi ${ }^{1, *}$, Indrasurya B. Mochtar ${ }^{2}$, Hera Widyastuti $^{2}$ \\ ${ }^{1}$ Doctoral Student, Department Civil Engineering and Planning, Institut Teknnologi Sepuluh Nopember, Indonesia \\ ${ }^{2}$ Department Civil Engineering and Planning, Institut Teknnologi Sepuluh Nopember, Indonesia
}

*Corresponding author: adhimuhtadi1974@gmail.com

\begin{abstract}
TransJakarta since 2004 was expected as the backbone of the public transportation in Jakarta as well as TransMilenio in Bogota. However, the role of TransJakarta only approximately $1,95 \%$ of the overall number of trips has reached 19 million/day. The analysis technique on this paper is descriptive analysis. TransJakarta operational perceived is still not effective, so that the necessary efforts to increase modal share sourced from BRT management best practice in other countries. Efforts could be made to increase modal share, among others, the elimination of thousands of parking and replaced by pedestrian friendly also develop a separate bike lane along $303 \mathrm{~km}$ in Bogota (Colombia). TransJakarta operational is still considered less in some aspects that are: total of fTransJakarta fleet, total of feeder route, Transjakarta speed and headway still need improved, overtaking lanes are built along the TransJakarta route, Integration with all public transport is absolutely necessary, integration with pedestrians and bicycle users TransJakarta ticket fares should be integrated with feeder and other public transportation such as KRL, city buses and paratransit and using smartcards. In terms of restrictions on the use of private vehicles can be done in the following ways implement a bike-sharing program, implement program of not using motor vehicles during weekdays for 1 day in a week, providing park and ride, implement fuel restriction program for gasoline purchases, implement car sharing program. If the operational performance of TransJakarta has been improved and restrictions on the use of private motor vehicles are implemented, it is expected that the modal split of road users in Jakarta can be expected to rise to be more ideal. In some other parts of the world some experts say ideal conditions of split capital between public transport and private vehicles can reach 65\%: $35 \%$. Hopefully the city of Jakarta can achieve this.
\end{abstract}

Keywords_-TransJakarta, best practices, BRT, modal share.

\section{INTRODUCTION}

$\mathrm{T}$ his Transjakarta is a BRT system implemented based on the success of Transmilenio in Bogota. One of Transjakarta's problems found is poor overall performance (high cost / low passenger numbers). The recommendation to improve Transjakarta's performance is develop short term improvement practices and systems ${ }^{[1]}$. However, in this paper, there is no explanation how to develop improvement practices and systems with optimal output on short term.

Other research indicates that there is a decreasing trend on amount of Transjakarta passengers. This is allegedly due to more passenger complaints to Transjakarta operations. Effective complain handling was done by review several variables such as reliability, responsiveness, assurance, empathy and tangibles ${ }^{[2]}$. This research also has not touched on how to develop improvement practices and systems with optimal output on short term.

The research has been done through several dimensions of SERVQUAL (physical appearance, performance, reliability, empathy and assurance) on public transportation in Jakarta. The results show that the improvements required are in terms of physical facility improvement, driver capability, ticket officer, shelter security officer and conductor ${ }^{[3]}$. The results of this study have not discussed the performance improvement of Transjakarta how to develop in short term improvement practices and systems optimally.

Research for planned Transjakarta feeder line was also implemented in year 2014. The results showed Transjakarta requires 6 additional routes for feeder ${ }^{[4]}$. So the results of research has not discussed the best practices of other BRT systems in other countries that can be applied in Jakarta as will be discuss in this paper.

\section{THE MATERIAL AND METHOD}

The present study uses qualitative as the method of study. Qualitative method is a research procedure which produces descriptive data in form of written or verbal words from people who are approached as the research sample that are observed ${ }^{[5]}$. Meanwhile the aim of qualitative study is to achieve complete picture about the research object that are examined.

For writing this paper using qualitative research. Because the research team tries to explore some positive things related to BRT operational in 7 other countries. The seven countries are Colombia (Bogota), Brazil (Rio de Janeiro and Curitiba), Mexico (Mexico City), China (Guangzhou), Iran (Tehran), Turkey (Istanbul), and Taiwan (Taipei). As BRT operates in 8 cities and 7 countries across the world, it is necessary to review secondary data of other researchers related to BRT's best practices in each of these cities. 
August $1^{\text {st }}-2^{\text {nd }}$ 2017, Surabaya - Indonesia

Data uses in the present study are secondary data in which it is collected by other researchers in numerous journals or studies. It is used to support primary information that is taken from numerous references, literatures, previous research, books and other sources.

Data collection is an essential activity for researcher since it can be used to determine achievement of the study. Therefore, data collection needs to be conducted carefully. Data collection uses in the present study is literature review.

Literature review is conducted to enrich knowledge concerning numerous concepts that are used as basic or guidance within research process. Literature review in collecting data within the present study is secondary data that is used to support research process in collecting information from numerous sources such as news, articles, books and journals. The objective of literature review is to seek facts and mastering the concept method that will be used.

Data analysis is a systematic process in seeking and compiling data based on interview, field note, and other resources thereby the data can be understood easily and result can be informed to other people. Moreover, qualitative analysis is an analysis that not approaching mathematics, statistics, and other model ${ }^{[5]}$. Analysis process uses in the present study is Miles and Huberman model $^{[6]}$ that approaching data reduction, data display, conclusion and triangulation. Descriptions regarding data analysis within the present study are as follow:

1. Data Reduction

Data reduction is selecting process, focusing attention on simplification, abstraction, and data transformation based on the field note. Data reduction is taken continuously during the present study performed. The next processes whole data reduction is performed are:

a. Coding is a process which sorts the data into similar category.

b. Data interpretation is seeking further information concerning data that have been analysed or in other words interpretation is detail description of the data research. The present study select the data based on information about the scholar opinions concerning the issue, classify it and determined using simple approach.

2. Data Display

In this step, researchers of the present study develop a description of information to make conclusion and decision. The data that is presented in the present study is narrative text. It is classified according to scholar opinions, concluded and presented in form of narrative text.

3. Conclusion/Verifying

Researchers attempt to conclude and verify the conclusion by seeking the signification coupled with indications that are collected in the field, noting regularity and configuration that may occur, observing causality of phenomena and its portions. In this stage, the researchers produce conclusion based on the data which also followed by matching note and observation result that are conducted by the researchers during this research.

\section{RESULT AND DISCUSSION}

\section{BRT Bogota}

Population of Bogota in 2014 was around 7.760.500 people. Population density was around 3347,4 person $/ \mathrm{km}^{2}$. GDP per person in 2015 was around US\$ 6056 (Rp. 80.837.305,-) with currency US\$ $1=$ Rp. $13.348,3,-$. Or in other words GDP per month is around Rp.6.736.442,-

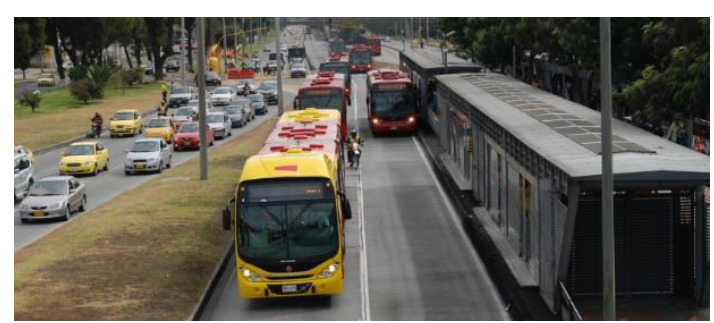

Fig 1. TransMilenio Bogota Source: colombiainfo.org (2015)

BRT system in Bogota (Colombia) is known as Trans Milenio. This system is operated since 2000 and it is operated by a company named TransMilenio S.A. Ticket price for this transportation is US\$ 0, 66 (Rp. 8.810,-). TransMilenio uses smartcard post-paid which can be bought inside the corridor to avoid long queue. Management systems of the ticket such as production, sales, installation, and maintenance are handled by TransMilenio S.A. ${ }^{[7]}$.

TransMilenio ticket is integrated with another public transportation such as traditional bus. Traditional bus consists of 3 type vehicles which are big, middle and small bus (van or minivan). Infrastructure cost per kilometre is around US\$26.530 (Rp. 354.130.399,-)

Main Features of TransMilenio are:

- This system is built gradually in order to fulfil $80 \%$ the demand of city transportation ${ }^{[17]}$

- Each corridor is built along main road of the city and moreover shuttle bus, repair shop, bridge and other infrastructures are built using public finance.

- TranMilenio operates under partnership mechanism between state and private company. The state responsible to develop and maintain infrastructures (through Urban Development Institute) meanwhile the private company responsible for planning, management and service control (throughTransmilenio S.A. as the private operator). At the beginning, partnership system is operated using $3 \%$ commission from the fare in which the commission is aroused simultaneously ${ }^{[8]}$.

- Subsidy is not applied for BRT

- Articulated bus is operated in all corridors.

- In 2011, 1.262 single buses have been upgraded into articulated bus in which those buses are operated in all over city, 519 conventional buses are added along 12 metre with 83 bus ${ }^{[8]}$

- Each articulated bus is able to carry 160 passengers in which 112 passengers are standing and 48 seats. 
- $\quad$ BRT is managed by private company that held contract with government and connector bus to BRT is managed by 11 other private companies.

- Numerous busses stop in every station meanwhile rest of the buses have express service.

- Passengers are getting the bus in special shuttle in which it is facilitated with pedestrian bridge to avoid accident and minimize the bus delay.

- Passengers should afford smart card before boarding and the transfer bus to BRT is free of charge ${ }^{[8]}$.

- Transmilenio S.A. monitors and controls BRT system by utilizing GPS coupled with wireless communication system for the driver of BRT.

- The duration of replacement for the bus is conducted regularly every 10 years although it can be prolonged until 15 years when the mileage of the bus is not reaching the maximum limit.

- Bus drivers get salary from the bus company

There are 9 integrated terminals and 11 corridors in Bogota Colombia. Length of the corridor is around 113 $\mathrm{km}$; it has 107 route feeders and 139 shuttle buses which the distance for each shuttle is around 812.2 metre. Real time information displays are provided in every shuttle and terminal to provide information to all travellers about the bus schedule ${ }^{[9]}$.

BRT provides 2 kinds of service in which express service (stop only in view shuttle) and standard service (stop in all shuttles). Moreover, BRT operates two kinds of busses which are articulated bus that suitable for 160 passengers and feeder (transfer) bus. Average departure of the bus within rush hours is 320 units. Total numbers of single bus that operate are 1,379 buses in which the average usage of the bus is around 6.5 year. Furthermore, the total numbers of articulated bus that operate are 230 units in which the average usage of the bus is around 1.9 year.

There are various ways in accessing TransMilenio such as: feeder system (26\%), traditional bus (20\%), regional bus $(5 \%)$, pedestrian $(47 \%)$ and cycling $(2 \%)^{11]}$. Meanwhile hare model for the public transportation in Bogota is bus $(73 \%)$ and BRT $(27 \%)^{[10]}$.

Operational average for this transportation is 26.2 $\mathrm{km} /$ hour in which the average speed for BRT express route is $30 \mathrm{~km} /$ hour and for all stop-services is 21 $\mathrm{km} /$ hour. Headway of BRT or waiting average for this transportation is around 2 minutes or 30 buses per hour ${ }^{[10]}$. Average departure for this transportation in weekday and weekend is as follow: conventional bus is around 15 units per hour, feeder bus is around 6 units per hour, and BRT is around 30 units per hour ${ }^{[10]}$. Occupancy average of the bus is around $80 \%$ in rush hour and $70 \%$ in ordinary hour ${ }^{[11]}$. TransMilenio has overtaking lanes which aims to overtake other vehicles.

Average numbers of passenger within rush hour are around 48,000 passengers per hour per direction. The total numbers of passenger in per day are around $2,213,236$ in which the average passengers in a year are around $565,100,000$ and the bus productivity per day is around 1,293 passengers $^{[12]}$.

At the beginning, citizen of Bogota prefer to use private vehicle instead of public transportation since
$95 \%$ of road users are private vehicle ${ }^{[13]}$. Bogota share model for transportation in 2010 is $59 \%$ for public transportation, $26 \%$ for private vehicle and $15 \%$ for nonmotorized vehicle.

Provision for private vehicle in Bogota is enacted in which the government provides lane along $330 \mathrm{~km}$ special for bicycle. It is aimed to facilitate people to go from their house into nearest shuttle bus by using bicycle. Furthermore, the government imposes car free day in day off which is started from $07.00-14.00$. In Bogota city centre, thousand parking areas are changed into pedestrian access to facilitate people walk into shuttle bus. Implementation of regulation concerning odd and even of vehicle registration number is able to reduce the number of private vehicle in the road up to $40 \%$. Moreover, private vehicle is not allowed to numerous main roads since those roads are allowed only for bus [14].

Benefits that are achieved from the operational of TransMilenio, TDM (Traffic Demand Management) and use of non-engine vehicle are: (1) Users of TransMilenio will save their time up to 223 hour per year, since the duration of travel is reduced up to $32 \%$ per day ${ }^{[13]}$, (2) This transportation is able to reduce emission of $\mathrm{CO}_{2}$ up to $318 \mathrm{~m}^{3}$ per day since 1997 . Most of the reduction is coming from car, taxi, bus and motorcycle ${ }^{[15]}$. The high number of people riding bicycle in Bogota is supported by large number of bridge as the form of infrastructure development ${ }^{[29]}$.

\section{BRT Curitiba}

Population number of Curitiba city in 2014 was around 5,048,062 people. Population density in this city was around 179, 6 people per $\mathrm{km}^{2}$. GDP per capita in 2015 was around US\$ 8,539 (Rp. 113.981.133,-) with currency US\$ $1=$ Rp. 13, 348.3,-. In other words GDP per month was around Rp. 9,498,427.-.

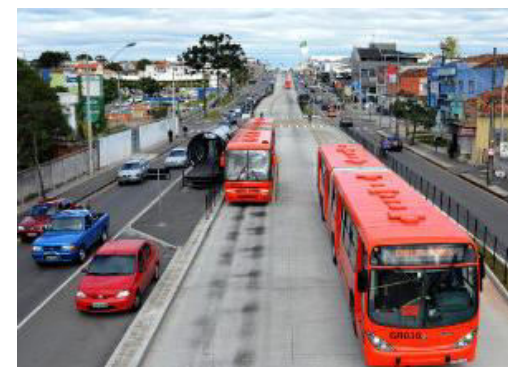

Fig. 2 BRT Curitiba (Brazil)

Source:curitibainenglish.com (2012)

In implementing public transportation system that rely on bus in 1972 precisely in the next 2 years after BRT Curitiba operated, numerous parking area in the main roads in Curitiba was changed into pedestrian facilities. The name of BRT in Curitiba (Brazil) is Rede Integrada de Transporte. The operational system of this BRT is operated since 1974 and it is operated by company named URBS. The fare ticket for standard service is US\$ 1.30 (Rp. 1,7352.-) meanwhile fare ticket for a year is US\$ 168.52 (Rp. 2,249,455.-). BRT ticket is integrated with all corridors in Curitiba.

Curitiba BRT has 4 types of bus which are express, feeders, neighbourhood and direct. Express bus uses articulated bus with 25 metre length and its capacity is 270 passengers. 
August $1^{\text {st }}-2^{\text {nd }}$ 2017, Surabaya - Indonesia

The operational system for this BRT operates 15 bus terminals, 11 corridors in which the length of each corridor is around $77 \mathrm{~km}, 106$ bus shelters in which the distance for each shelter is around 722.6 metre. In each terminal and shelter, real time information display is provided to facilitate travellers in finding the bus schedule ${ }^{[9]}$.

Operational average for this transportation is 19 $\mathrm{km} /$ hour. Headway of BRT or waiting average for this transportation is around 3 minute. Average departure for this transportation in rush hour is around 67 units per hour. Only view routes have overtaking lanes which aim to overtake other vehicles.

Average numbers of passenger within rush hour are around 20,500 passengers per hour per direction. The total numbers of passenger in per day are around 619,500 passengers in which the average passengers in a year are around 565,100,000 ${ }^{[10]}$

Service characters of Curitiba BRT are low cost and comfortable therefore it becomes the main option for traveller. It influences the displacement of private into public transportation which reaches $28 \%$. In a year, it decreases the number of mobility up to 27 million in which it also decreases engine usage up to 27 million litres. Curitiba citizen consume $10 \%$ of their salary for transportation in which it is the lowest among other 8 cities that operate BRT ${ }^{[16]}$. Curitiba share model for transportation is $46 \%$ for public transportation, $26 \%$ for private vehicle and $28 \%$ for non-motorized vehicle

\section{BRT Rio de Janeiro}

Population number of Rio de Janeiro in 2014 was around 6,476,631 people. Population density in this city was around 2,209 people per $\mathrm{km}^{2}$. GDP per capita in 2014 was around US\$ 8,539 (Rp. 113.981.133,-) with currency US\$ $1=$ Rp. 13, 348.3,-. In other words GDP per month is around Rp. 9,498,427.-.

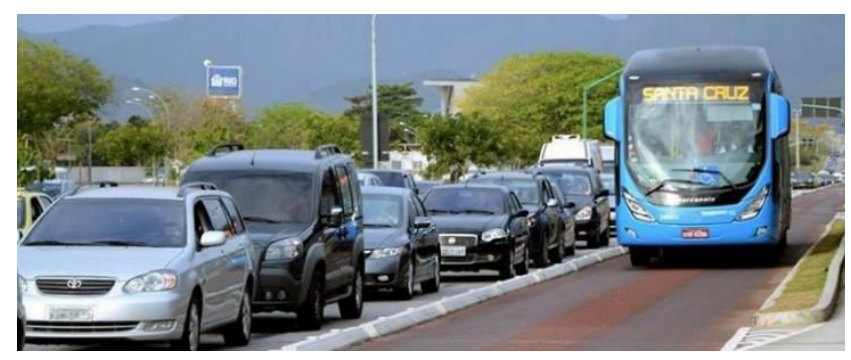

Fig 3. BRT Rio de Janeiro (Brazil)

Source: smartcities.com (2016)

The name of BRT in Rio de Janeiro (Brazil) is BRT Rio. The operational system of this BRT is operated since 2011 and it is operated by company named SMRT. BRT Rio has 8 integrated terminals, 17 corridors in which the length of each corridor is around $168 \mathrm{~km}, 49$ transfers route, 240 bus shelters in which the distance of each shelter is around 700 metre.

In each terminal and shelter, real time information display is provided to facilitate travellers in finding the bus schedule Fare ticket for standard service is US\$ 1.16 (Rp. 15,484). Ticket of BRT Rio is integrated with all corridors in Rio de Janeiro.

Operational average for this transportation is 21.8 $\mathrm{km} /$ hour. Headway of BRT or waiting average for this transportation is around 3 minute. Average departure for this transportation in rush hour is around 382 units per hour. Only view routes have overtaking lanes which aim to overtake other vehicles.

The total numbers of articulated bus that operate are 2182 units in which the average usage of the bus is around 2 year. Meanwhile the total numbers of double articulated bus are 2 units in which the average usage of the bus is around 1 year.

Average numbers of passenger within rush hour are around 65,400 passengers per hour per direction. The total numbers of passenger in per day are around $3,172,600$, passengers in which the average passengers in a year are around $951.780 .000^{[33]}$. Rio de Janeiro share model for transportation is $48.7 \%$ for public transportation, $19.5 \%$ for private vehicle and $31.8 \%$ for non-motorized vehicle

\section{BRT Mexico City}

Population number of Mexico City in 2010 was around $8,851,080$ people. Population density in this city was around 2,451 people per $\mathrm{km}^{2}$. GDP per capita in 2015 was around US\$ 9,009 (Rp. 120.254.835,-) with currency US\$ $1=$ Rp. 13, 348.3,-. In other words GDP per month was around Rp. 10,021,236.-

The name of BRT in Mexico City is Metrobus. The operational system of this BRT is operated since 2005 and it is operated by company named METROBUS Metrobus has 10 integrated terminals, 6 corridors in which the length of each corridor is around $125 \mathrm{~km}, 40$ transfers route, 240 bus shelters in which the distance of each shelter is around 665 metre.

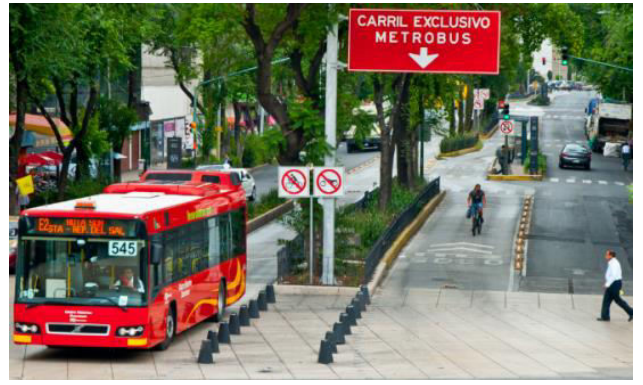

Fig 4. BRT Mexico City (Metrobus) Source: cityclock.org (2014)

Infrastructure cost $/ \mathrm{km}$ is around US\$ 2,880 (Rp. $38,443,104 .-)$. In each terminal and shelter, real time information display is provided to facilitate travellers in finding the bus schedule Fare ticket for standard service is US\$ 0.32 (Rp. 4,272). Ticket of Metrobus is integrated with all corridors in Mexico City.

Speed average in the city centre is $18 \mathrm{~km} /$ hour $^{[30]}$ Average departure for this transportation in rush hour is around 77 units per hour. Only view routes have overtaking lanes which aim to overtake other vehicles.

The total numbers of bus using diesel \& hybrid engine are 1,300 units. Meanwhile it has 452 articulated buses. Average usage of diesel \& hybrid engine is 3.5 year. The total numbers of double articulated bus are 1,450 units in which all of those units are using diesel and hybrid engine. The average usage of those units is 3.5 year.

Average numbers of passenger within rush hour are around 12,000 passengers per hour per direction. The total numbers of passenger in per day are around $1,100,000$ passengers in which the average passengers in a year are around $330,000,000^{[33]}$. Mexico City share model for transportation is $77.9 \%$ for public 
August $1^{\text {st }}-2^{\text {nd }}$ 2017, Surabaya - Indonesia

transportation, $20.7 \%$ for private vehicle and $1.4 \%$ for non-motorized vehicle

\section{BRT Guangzhou}

Population number of Guangzhou city in 2010 was around 6,780,000 people. Population density in this city was around 1,764 people per $\mathrm{km}^{2}$. GDP per capita in 2015 was around US\$ 7,925 (Rp. 105,285.278.-) with currency US\$ $1=$ Rp. 13, 348.3,-. In other words GDP per month was around Rp. $8,815,430$.-

The name of BRT in Guangzhou City is Guangzhou BRT. The operational system of this BRT is operated since 2010 and it is operated by company named BRT Operation and Management Company. Guangzhou BRT does not have integrated terminals, 1 corridor in which the length of corridor is around $23 \mathrm{~km}, 3$ transfers route, 26 bus shelters in which the distance of each shelter is around 808.8 metre. Fare ticket for standard service is US\$ 0.3 (Rp. 4,005).

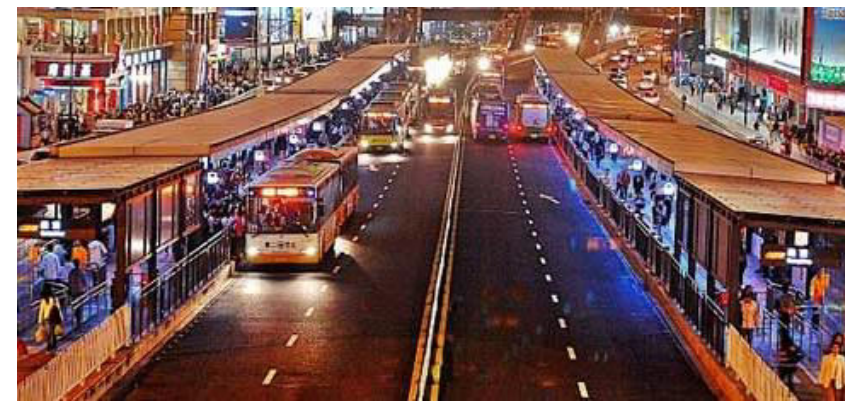

Fig 5. Guangzhou BRT (China)

Source: guanzhoutravelguide.com (2011)

Speed average in the city centre is $24.8 \mathrm{~km} /$ hour $^{[30]}$. Average departure for this transportation in rush hour is around 35 units per hour. It does not have overtaking lanes which aim to overtake other vehicles. The total numbers of bus are 989 units in which it uses LPG as the fuel engine.

Average numbers of passenger within rush hour are around 27,000 passengers per hour per direction. The total numbers of passenger in per day are around 850,000 , passengers in which the average passengers in a year are around 225,000,000 ${ }^{[12]}$. Guangzhou City share model for transportation is $32 \%$ for public transportation, $21 \%$ for private vehicle and $47 \%$ for non-motorized vehicle

Numerous characteristics for Guangzhou city are cycling lanes are continuously provided along the bus corridors and it also supported with 5,500 park area for bicycle nearby the bus shelter area ${ }^{[28]}$. Guangzhou BRT is able to decrease high volume of traffics and it also able to decrease the emission of $\mathrm{CO}_{2}$ around 86, 000 ton per year. Travel duration is raised between 20 up to $29 \%$ in view roads that are passed by Guangzhou BRT.

\section{BRT Tehran}

Population number of Tehran (Iran) in 2012 was around $13,828,365$ people. Population density in this city was around 10,854 people per $\mathrm{km}^{2}$. GDP per capita in 2015 was around US\$ 5,443 (Rp. 72,654,797.-) with currency US\$ $1=$ Rp. 13, 348.3,-. In other words GDP per month was around Rp. 6,054,566.--

The name of BRT in Tehran is Tehran BRT. The operational system of this BRT is operated since 2010 and it is operated by company named Tehran
Transportation and Traffic Agency. Tehran BRT has 6 has integrated terminals, 8 corridors in which the length of each corridor is around $130 \mathrm{~km}, 10$ transfers route, 155 bus shelters in which the distance of each shelter is around 915 metre. Fare ticket for standard service is US\$ 0.6 (Rp. 8,009).

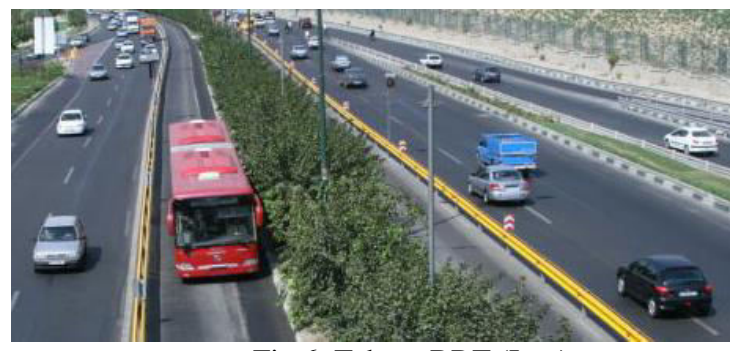

Fig 6. Tehran BRT (Iran)

Source: en.tehran.ir (2017)

Speed average in the city centre is $19 \mathrm{~km} / \mathrm{hour}^{[33]}$ The total numbers of bus are 1,240 units in which it consists of 660 units for standard bus and 580 units for articulated bus. Average departure for this transportation in rush hour is around 90 units per hour. It does not have overtaking lanes which aim to overtake other vehicles.

The total numbers of passengers within rush hour is not known. The total numbers of passenger in per day are around 2,000,000 passengers in which the average passengers in a year are around 600,000,000 [12] meanwhile modal share of transportation for Tehran is not known.

\section{BRT Taipei}

Population number of Taipei in 2012 was around $6,950,646$ people. Population density in this city was around 2,764 people per $\mathrm{km}^{2}$. GDP per capita in 2015 was around US\$ 20,925 (Rp. 279,313.178.-) with currency US\$ 1 = Rp. 13, 348.3,-. In other words GDP per month was around Rp. 23,276,098.--

The name of BRT in Taipei is Busways. The operational system of this BRT is operated since 1998. The Busways has 10 terminals, 1 corridor in which the length of the corridor is around $60 \mathrm{~km}$, it does not have transport route and the distance of each shelter is around 380 metre. Infrastructure cost $/ \mathrm{km}$ is around US\$ 350,000 (3 Billion Rupiah-). The ticket fare is not known meanwhile speed average in the city centre is 19.5 $\mathrm{km} /$ hour ${ }^{[12]}$. The total numbers of bus are 1,680 units in which it uses diesel fuel engine.

Average numbers of passenger within rush hour are around 9,500 passengers per hour per direction. The total numbers of passenger in per day are around 1,200,000 passengers in which the average passengers in a year are around $360,000,000^{[12]}$. Mexico City share model for transportation is $34 \%$ for public transportation, $47 \%$ for private transportation and $19 \%$ for non-motorized vehicle 
August $1^{\text {st }}-2^{\text {nd }}$ 2017, Surabaya - Indonesia

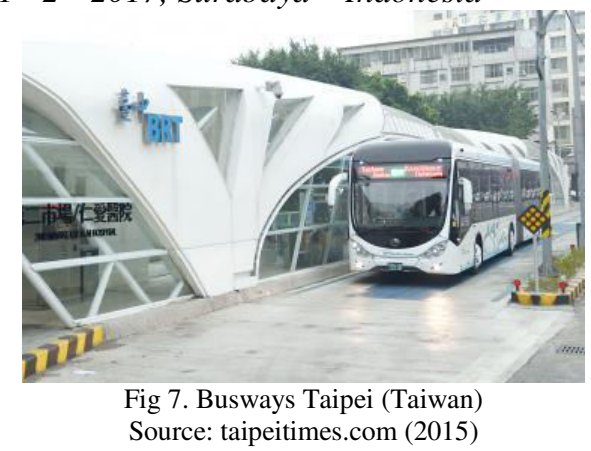

\section{BRT Istanbul}

Population number of Istanbul (Turkey) in 2014 was around $14,160,147$ people. Population density in this city was around 2,523 people per $\mathrm{km}^{2}$. GDP per capita in 2015 was around US\$ 9,130 (Rp. 71,869,979.-) with currency US\$ 1 = Rp. 13, 348.3,-. In other words GDP per month was around Rp. 10,155,831.-.

The name of BRT in Istanbul is Metrobus. The operational system of this BRT is operated since 2007 and it is operated by company named IETT. Minibus has 3 integrated terminals, 1 corridor in which the length of the corridor is around $52 \mathrm{~km}, 1$ transfer route, and 44 bus shelters. Fare ticket for standard service is US\$ 0.97 (Rp. 12,947).

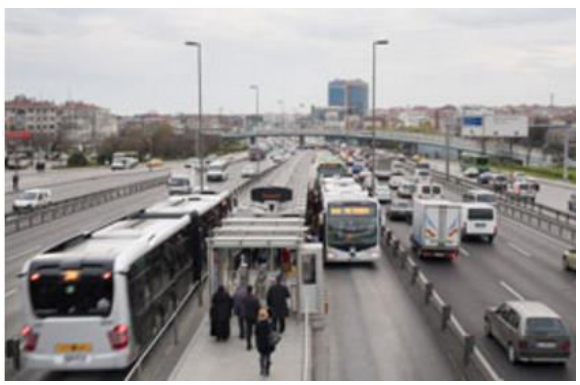

Fig 8. Metrobus Istambul (Turki)

Source: traffictechnologytoday.com (2017)

Speed average in the city centre is $35 \mathrm{~km} /$ hour $^{[12]}$. The total numbers of bus are 1,600 units which all of the bus using diesel engine. Moreover, it consists of 1300 units for standard bus and 300 units for articulated bus. It does not have overtaking lanes which aim to overtake other vehicles.

Average numbers of passenger within rush hour are around 30,000 passengers per hour per direction. The total numbers of passenger in per day are around 750,000 passengers in which the average passengers in a year are around $225,000,000^{[33]}$. Istanbul share model for transportation is $36 \%$ for public transportation, $15 \%$ for private vehicle and $49 \%$ for non-motorized vehicle.

\section{BRT Jakarta}

Population number of Jakarta (Indonesia) in 2011 was around $9,607,787$ people. Population density in this city was around 3,830 people per $\mathrm{km}^{2}$. GDP per capita in 2015 was around US\$ 3,347 (Rp. 44,676,760.-) with currency US\$ $1=$ Rp. 13, 348.3,-. In other words GDP per month was around Rp. 3,723,063.--

The name of BRT system and its operator in Jakarta is Transjakarta. It is opened in 2004 in which it has 240 BRT shelters, 12 corridors with its length is around $206.75 \mathrm{~km}$.

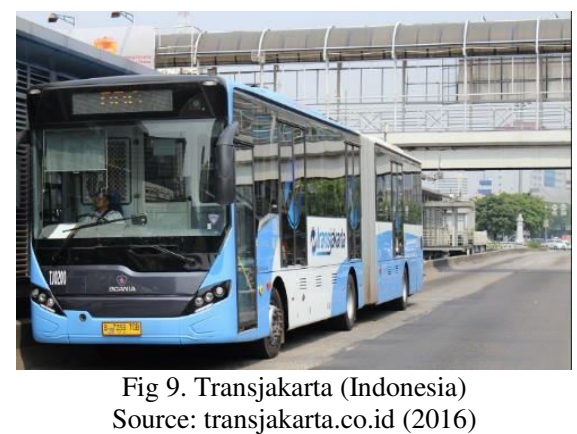

Transjakarta has 10 feeder routes, 150 shelters in which the distance for each shelter is around 971 metre. The ticket fare is Rp. 3,500 (US\$ 0.26). The average of operational speed is $19 \mathrm{~km} /$ hour ${ }^{[12]}$. The total numbers of bus are 1,233 units in which all of the buses are using $\mathrm{CNG} \&$ diesel engine fuel. Capital cost $/ \mathrm{km}$ is around US $\$ 1,400$ (Rp. 18,687,620). The average frequencies of departure within rush hour are around 40 buses per hour. Only view routes have overtaking lanes which aim to overtake other vehicles.

Average numbers of passenger within rush hour are around 4,000 passengers per hour per direction. The total numbers of passenger in per day are around 370,000 passengers in which the average passengers in a year are around $114,783,774^{[12]}$. Istanbul share model for transportation is $36 \%$ for public transportation, $41 \%$ for private vehicle and $23 \%$ for non-motorized vehicle. Transjakarta operational system has changed people perspective in transporting since $14 \%$ private vehicle travellers switch using BRT ${ }^{[17]}$

The main shortcomings of Transjakarta are concerning duration of the queue coupled with inappropriate of bus frequencies. It is influenced by low access of passengers within the corridors, in-efficient of informational system since every shelter only supported by ticketing staff, security and display board ${ }^{[18]}$.

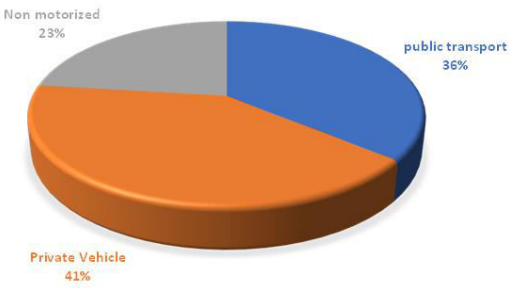

Fig 9. Split Model in Jakarta (Indonesia) Source: brtdata.org (2009)

Here is presented comparison of 9 BRT in the world in terms of headway and speed on Table 1.

Table 1. Comparison of BRT data from headway, total fleet and speed

\begin{tabular}{|c|c|c|c|c|c|}
\hline \multirow{2}{*}{ No. } & \multirow{2}{*}{ City } & \multicolumn{2}{|c|}{ Headway } & \multirow{2}{*}{$\begin{array}{l}\text { Total } \\
\text { Fleet }\end{array}$} & \multirow{2}{*}{ Speed } \\
\hline & & minutes & seconds & & \\
\hline 1 & Bogota & 0.17 & 10.20 & 1,379 & 26.2 \\
\hline
\end{tabular}




\begin{tabular}{|l|l|c|c|c|c|}
\hline 2 & Curitiba & 1.50 & 90.00 & 1,200 & 19 \\
\hline 3 & $\begin{array}{l}\text { Rio de } \\
\text { Janeiro }\end{array}$ & 4.00 & 240.00 & 2,182 & 21.8 \\
\hline 4 & Mexico City & 1.09 & 65.45 & 2,750 & 18 \\
\hline 5 & Guangzhou & 0.17 & 10.00 & 989 & 24.8 \\
\hline 6 & Tehran & 5.45 & 327.27 & 1,240 & 19 \\
\hline 7 & Taipei & 0.50 & 30.00 & 1,680 & 19 \\
\hline 8 & Istanbul & 0.23 & 14.00 & 1,600 & 35 \\
\hline 9 & Jakarta & 4.00 & 240.00 & 1,223 & 19 \\
\hline
\end{tabular}

Source: brtdata.org (2017)

\begin{tabular}{|c|c|c|c|c|}
\hline 3 & $\begin{array}{c}\text { Rio de } \\
\text { Janeiro }\end{array}$ & 17 & 168 & $3,172,600$ \\
\hline 4 & Mexico City & 6 & 125 & $1,100,000$ \\
\hline 5 & Guangzhou & 1 & 23 & 850,000 \\
\hline 6 & Tehran & 8 & 130 & $2,000,000$ \\
\hline 7 & Taipei & 1 & 60 & $1,200,000$ \\
\hline 8 & Istanbul & 1 & 52 & 750,000 \\
\hline 9 & Jakarta & 12 & 207 & 370,000 \\
\hline
\end{tabular}

Source:brtdata.org (2017)

From Table 1 above it can be shown that the TransJakarta headway is just above Tehran and the same as in Rio de Janeiro only 4 minutes. This indicates that the TransJakarta headway still needs to be increased in the range of 10 - 20 seconds as well as in Bogota, Guangzhou and Istanbul. The number of TransJakarta buses is only 1223 units serving 12 corridors. While the BRT Istanbul although only 1 corridor but has fleet reach 1600 units. This shows the lack of Transjakarta fleet which resulted in high headway and low operational speed. So the waiting time at the bus stop and travel time will be longer than other BRTs.

Table 2. Comparison of BRT data from fare, meal and GDP

\begin{tabular}{|l|l|c|c|c|}
\hline No. & \multicolumn{1}{|c|}{ City } & $\begin{array}{c}\text { Fare } \\
\text { (US\$) }\end{array}$ & $\begin{array}{c}\text { Meal/ } \\
\text { Fare }\end{array}$ & $\begin{array}{c}\text { GDP/Capita } \\
\text { (US\$) }\end{array}$ \\
\hline 1 & Bogota & 0.66 & 7.74 & 6,056 \\
\hline 2 & Curitiba & 1.3 & 5.86 & 8,539 \\
\hline 3 & $\begin{array}{l}\text { Rio de } \\
\text { Janeiro }\end{array}$ & 1.16 & 6.83 & 8,539 \\
\hline 4 & Mexico City & 0.32 & 21.64 & 9,009 \\
\hline 5 & Guangzhou & 0.3 & 13.99 & 7,925 \\
\hline 6 & Tehran & 0.6 & 8.76 & 5,443 \\
\hline 7 & Taipei & 0.45 & 8.83 & 20,925 \\
\hline 8 & Istanbul & 0.97 & 4.28 & 9,130 \\
\hline 9 & Jakarta & 0.26 & 13.31 & 3,347 \\
\hline
\end{tabular}

Source: brtdata.org (2017)

From Table 2 above it can be shown that the cheapest ticket price rank 3 is Transjakarta. Transjakarta tickets are only lost by Mexico City and Guangzhou. However, in terms of GDP, Jakarta is the lowest among other cities. This shows that although tickets are fairly cheap, travelers in Jakarta are not necessarily using TransJakarta. This is very likely due to motor vehicle and motor vehicle operational activities are still affordable among the citizens of Jakarta. As is known, the increase of motorcycles reach 4000 until 4500 units per day while the increase of the car reaches 1600 units per day.

Table 3. comparison of BRT data from corridor, length and passenger/day

\begin{tabular}{|c|c|c|c|c|}
\hline No. & City & Corridor & $\begin{array}{c}\text { Length } \\
(\mathbf{K m})\end{array}$ & $\begin{array}{c}\text { Passenger/ } \\
\text { Day }\end{array}$ \\
\hline 1 & Bogota & 11 & 113 & $2,213,236$ \\
\hline 2 & Curitiba & 11 & 81 & 619,500 \\
\hline
\end{tabular}

From Table 3 it can be seen that although the number and length of the TransJakarta corridor is at most, but the number of passengers / day is the least among other cities running BRT. This is most likely due to the unrelated TransJakarta with other public transportation such as conventional city buses, paratransit, KRL (electric train), taxi and bajaj. The existence of park and ride that has not yet integrated with the bus stop and the BRT terminal is also very likely to be the cause of the lack of interest in Transjakarta compared to other cities of BRT organizers.

Table 4. Comparison of moda split data

\begin{tabular}{|l|l|c|c|c|}
\hline \multirow{2}{*}{ No } & \multirow{2}{*}{ City } & \multicolumn{3}{|c|}{ Modal Split } \\
\cline { 2 - 5 } & & PT & PV & NMV \\
\hline 1 & Bogota & 59 & 26 & 15 \\
\hline 2 & Curitiba & 46 & 26 & 28 \\
\hline 3 & $\begin{array}{l}\text { Rio de } \\
\text { Janeiro }\end{array}$ & 48.7 & 19.5 & 31.8 \\
\hline 4 & $\begin{array}{l}\text { Mexico } \\
\text { City }\end{array}$ & 77.9 & 20.7 & 1.4 \\
\hline 5 & Guangzhou & 32 & 21 & 47 \\
\hline 6 & Tehran & 54 & 39 & 7 \\
\hline 7 & Taipei & 34 & 47 & 19 \\
\hline 8 & Istanbul & 36 & 15 & 49 \\
\hline 9 & Jakarta & 36 & 41 & 23 \\
\hline
\end{tabular}

Note: $\mathrm{PT}=$ Public Transport $; \mathrm{PV}=$ Private Vehicle;

$\mathrm{NMV}=$ Non Motorized Vehicle

Source: brtdata.org (2017)

From Table 4 it is found that the modal split for public transport in Jakarta is still 36\%. While Jakarta, which has BRT with the longest BRT lanes in the world still lags behind the use of public transportation compared to other cities. Especially when compared with Mexico City that the use of public transportation has reached $77.9 \%$. This indicates that use of public transport is still not a priority and there are still many homework related to the integration of public transport routes, the ticketing system for the whole public transport, the development of pedestrian and park and ride that support access to public transport and also very important private vehicle restrictions such as In cities that have successfully operated BRT.

Restrictions on vehicles that can be applied in Jakarta are as follows:

- Changing the $45 \mathrm{~km}$ highway for private vehicles into pedestrians and 1123 parks with seating and decorative lights as a means of access to the BRT that has been implemented in Bogota ${ }^{[19]}$ and Curitiba $^{[20]}$. At the pedestrian does not operate parking for motor vehicles such as those held in 
August $1^{\text {st }}-2^{\text {nd }}$ 2017, Surabaya - Indonesia

Mexico City ${ }^{[21]}$. Promoting car free areas and pedestrian zones in Tehran was implemented in Tehran's Traditional 'Bazaar' area. In 2008, the Municipality planned to construct a pedestrian only zone in some of the heavily populated streets surrounding the Bazaar. As this walkway ring is in near to the ' 15 Khordad' metro station, using public transport to reach to this area became much more attractive for people and especially for business people $^{[22]}$.

- Prioritize the existence of a bicycle by converting a lane for a motor vehicle into a $200 \mathrm{~km}$ bike special lane in Bogota ${ }^{[19]}$. It is also implemented in Rio de Janeiro ensuring that within a $5 \mathrm{~km}$ radius a person with cycling will get the closest BRT bus stop ${ }^{[23]}$. In Guangzhou the pedestrian bike pedestrian is named Greenways and has been opened for $6000 \mathrm{~km}^{\text {[24] }}$.

- Car free day implementation every weekend from $07.00-14.00$ in Bogota $^{[19]}$. Similarly, car free day is also held in Rio de Janeiro.

- Design a highway without any roadside parking facilities. So that in the absence of parking on the roadside operational BRT will not be hampered. This has been done in Curitiba ${ }^{[20]}$. Restrictions on private parking areas on the $\mathrm{CBD}$ in the city center. This will result in 70 until $75 \%$ of road users using public transport ${ }^{[20]}$. The highways in the CBD center of Curitiba are closed for private vehicle access ${ }^{[20]}$.

- There is a bike-sharing program implemented in Rio de Janeiro that makes it easy for travelers to the BRT Rio stop ${ }^{[23]}$. The integration between bike sharing under the name Ecobici and the BRT stop has also been implemented in Mexico City ${ }^{[21]}$. Guangzhou's bike sharing system is integrated too with the city's BRT ${ }^{[24]}$. Di Taipei juga dilaksanakan bike sharing dengan nama YouBike ${ }^{[25]}$. Tehran Cycling Board affiliated to the Cycling Federation of Iran organized a bike-sharing with 120 bikes. Bike sharing terminals will be set up across the capital as part of a bicycle-sharing initiative known as "Smart Bike Program" under the auspices of Tehran Municipality's transport and traffic Department $^{[22]}$.

- Integration of public transport between BRT and Metro (subway) was conducted in Rio de Janeiro ${ }^{[23]}$ and Taipei ${ }^{[25]}$, making it easier for travelers to move between public transport ${ }^{[23]}$. The integration between BRT and HSR (High Speed Rail) has also been implemented in Taipei ${ }^{[25]}$. Metrobüs Istanbul connects with regular IETT bus, subway, and light rail systems. IETT encourages multimodal trips by offering free transfers between Metrobüs and other $\operatorname{modes}^{[26]}$.

- Mexico City implemented Ecoparq which an electronic parking lot to squeeze leakage of parking revenues and as a source of city revenue for higher fees $^{[27]}$.

- In 1989, the government of Mexico City introduced a program, Hoy No Circula, that bans most drivers from using their vehicles one week-day per week on the basis of the last digit of the vehicle's license plate $^{[28]}$.
- Park-and-ride facilities to encourage motorists to access mass transit is found in Guangzhou and Taipei $^{[25]}$.

- In Tehran, everyone who owns a car is rationed to a maximum of 60 liters per month. How to purchase using a smart card that can identify the number of purchases that have been made and the identity of the buyer.

- Public transportation fares made very cheap ie Rp. 2,000, - / one way for city bus and Rp. 1000, - / one way for the train. Public transport is equipped with cooling in the summer and is equipped with heating in winter. Public transport in Tehran is known to be quite convenient and cheap.

- The Taipei City Government decided in 1999 declared integrated contactless card system (EasyCard) with to provide "one card for all", including the payment of car park in connection with the public transport network, and therefore to attract people "out of their cars". The EasyCard can use to the 6 metro lines, 5000 buses operated by 15 companies, 92 city owned parking lots and 3,000 on street parking spaces. EasyCard has been successful: there are now 13 million cards in circulation for a population of 6.4 million inhabitants. The benefits of EasyCard concern the passengers, as well as the Taipei City Government and the Public Transport Operators $^{[25]}$.

- Car sharing policies that share seats with other users are run in an effort to suppress individual car use that has been implemented in Istanbul ${ }^{[29]}$.

\section{CONCLUSIONS}

After completing Chapter 3 ie results and discussion, it is now time to make some conclusions from Chapter 3. TransJakarta operational is still considered less in some respects that are: (1) The number of TransJakarta fleet by covering 12 corridors reaches only 1223 buses. When compared to BRT Istanbul with 1 corridor alone has a bus fleet of 1600 bus BRT, (2) Feeder route only 10 routes very far behind with TransMilenio which has route feeder as many as 107 routes, (3) Transjakarta speed still need Improved. Average operating speed is still around $19 \mathrm{~km} / \mathrm{h}$. While Metrobus Istanbul can reach $35 \mathrm{~km} / \mathrm{h}$ and the speed of TransMilenio Bogota reached $26.2 \mathrm{~km} / \mathrm{h}$, (4) Headway TransJakarta also still need to be improved.

far behind with TransMilenio which has route feeder as many as 107 routes, (3) Transjakarta speed still need Improved. Average operating speed is still around 19 $\mathrm{km} / \mathrm{h}$. While Metrobus Istanbul can reach $35 \mathrm{~km} / \mathrm{h}$ and the speed of TransMilenio Bogota reached $26.2 \mathrm{~km} / \mathrm{h},(4)$ Headway TransJakarta also still need to be improved.

In terms of restrictions on the use of private vehicles can be done in the following ways: (1) Implement a bikesharing program that helps road users to use bicycles to the nearest BRT stops as in Rio de Janeiro, Mexico City, Guangzhou and Tehran, (2) Carry out a program of not using motor vehicles during weekdays for 1 day in a week such as those held in Mexico City, (3) Providing park and ride facilities so that road users using motor vehicles are willing to leave their vehicles and switch to public transport as well as in Guangzhou and Taipei, (4) 
August $1^{\text {st }}-2^{\text {nd }}$ 2017, Surabaya - Indonesia

Implement fuel restriction program for motor vehicles for example in 1 month maximum of 60 liter BBM which can be purchased using smartcard as done in Tehran, (5) Carrying out car sharing in order to suppress the use of taxis that are usually only used by one person only as implemented in Istanbul.

If the operational performance of TransJakarta has been improved and restrictions on the use of private motor vehicles are implemented, it is expected that the modal split of road users in Jakarta can be expected to rise to be more ideal. In some other parts of the world some experts say ideal conditions of split capital between public transport and private vehicles can reach $65 \%$ : $35 \%$. Hopefully the city of Jakarta can achieve this.

\section{REFERENCES}

[1] Elliot, Tom, "Transjakarta Improvement Program", MRCagney/ Indonesian Infrastructure Initiative, IABW Conference, Jakarta, 18 November 2015

[2] Wijaya, D. H., "Study of Service Quality in The Public Bus Transport: Customer Complaint Handling and Service Standards Design, Case Study: Transjakarta Busway and VarmLandsTrafik AB Bus", Karlstads Universitet, 2009

[3] Elida, T. and Didin Mukodim, "Quality of Service on Public Mass Transit in Jakarta", The 3rd UzbekistanIndonesia International Joint Conference on Economic Development and Nation Character Building to Meet the Global Economic Challenges, 2012.

[4] Stein, J.v., "Creating Feeder Bus Lines for Transjakarta $B R T$, Understanding spatial patterns of daily destinations from poverty origin zones in Jakarta to determine demand for a new feeder system of Transjakarta BRT", University of Twente, 2014

[5] B., Robert C., and S. J. Taylor, "Introduction to Qualitative Research Methods, A Phenomenological Approach The Social Sciences", New York, John Wiley and Sons., 1992

[6] Miles, M. B. dan Huberman, A. M., "Qualitative Data Analysis”, London, Sage Publishing, 1994

[7] Cain, A., Darido, G., Baltes, M.R., Rodriguez, P., Barrios, G and J.C. Barrios, "Applicability of Bogotá's Transmilenio BRT System to The United States", the Transportation Research Board's $86^{\text {th }}$, Annual Meeting, January 2007

[8] Hidalgo, D., L. Pereira, N. Estupinan, and P. L. Jimenez, "TransMilenio BRT System in Bogotá, High Performance and Positive Impact-Main Results of an Ex-Post Evaluation. Research in Transportation Economics 39(1): 133-138, 2013

[9] Levinson, H. S., et al., "Bus Rapid Transit: Synthesis of Case Studies", Washington DC, TRB annual meeting, 2003

[10] Batarce, M., Muñoz A., J.C., Ortúzar S., J. D., Raveau, S., Mojica, C., and R. A. Ríos, "Evaluation of Passenger Comfort in Bus Rapid Transit System, Infrastructure and Environment Sector, Transport Division, Inter-American Development Bank, 2015

[11] Cain, A., Darido, G., Baltes, M.R., Rodriguez, P., Barrios, G and J.C. Barrios, "Applicability of Bogotá's Transmilenio BRT System to The United States", the
Transportation Research Board's 86 ${ }^{\text {th }}$, Annual Meeting, January 2007

[12] www.brtdata.org, "Global BRT Data", diakses tanggal 12 May 2017

[13] UNDP, Special Unit for South - South Cooperation, "Bogotá, Colombia Bus Rapid Transit Project TransMilenio", Case Study (Transportation)

[14] Nicolai, J.C., and D. M. Weiss, "Influences on Operational Issues on the Operational Cost of BRT Buses and BRT Systems", Daimler Research Center Berlin; Proceeding of the $27^{\text {th }}$ Southern Africa Transport Conference (SATC 2008)

[15] Hook, W., "Reducing Transport Secrot GHG Emissions in Developing Countries: Lessons Learned from the GEF Transport Program", Paper read at Asilomar Conference on Transportation and Energy: Toward a Policy Agenda for Climate Change, 23 August - 25 August, at Davis, California, 2005

[16] Goodman, J., Laube, M. and Judith Schwenk, "Curitiba's Bus System is Model for Rapid Transit", Journal for Social and Environmental Justice: Race, Poverty \& The Environment; winter 2005/2006

[17] Susilo, Y. O., Juwono, T.B., Santosa, W. and D. Parikesit, "A Reflection of Motorization and Public Transport in Jakarta Metropolitan Area: Lessons Learned and Future Implications Towards Better Transportation Development in Developing Countries, Journal of Eastern Asia Society for Transportation Studies 7: 299-313, 2007

[18] Yunita, R., "TransJakarta: Putting on Lipstick While Running to Catch The Bus, Sustainable Transport 20: 5-7, 2008.

[19] Penalosa, Enrique, "Peran Transportasi Dalam Kebijakan Pengemangan Perkotaan", GTZ and Federal Ministry for Economic Coopertion \& Development, 2002

[20] Curitiba, Brazil, "BRT Case Study", 2000

[21] Baranda, Bernardo, "Historic Revival of at the Heart of Mexico City", New York: Sustainable Transport, ITDP, No. 24, Winter 2013

[22] Allen, Heather, An Integrated Approach to Public Transport, Tehran, Islamic Republic of Iran", Case study prepared for Global Report on Human Settlements, 2013

[23] ITDP Brazil, "Impact Analysis of Transoeste Bus Rapid Transit System in Rio de Janeiro”, April 2013

[24] van Ooijen, B. and S. Li, China Shows Leadership in Bike Share and Greenways", New York: Sustainable Transport, ITDP, No. 24, Winter 2013

[25] Feng, Cheng-Min, "Integrated Strategies for Sustainable Urban Transit", Urbanization, East Asia and Habitat II Section 2: Land Use Planning and Urban Congestion, 2002

[26] Yazıc1, .A., Levinson, H.S., Ilıcal1, M., Camkesen, N., and C. Kamga, "A Bus Rapid Transit Line Case Study: Istanbul's Metrobüs System, Journal of Public Transportation, Vol. 16, No. 1, 2013

[27] Kodranky, Michael,'Taming Mexico City's Parking Frenzy", New York: Sustainable Transport, ITDP, No. 24, Winter 2013

[28] Davis, Lcas W., "The Effect of Driving Restrictions on Air Quality in Mexico City", Journal of Political Economy, 2008, vol.116, no.1

[29] Lane, C., Zeng, H., Dhingra, C., and A. Carrigan, "Carsharing A Vehicle for Sustainable Mobility in Emerging Markets?”, World Resource Institute WRI Ross Center For Sustainable Cities, 2015 